Chemical Technology

Division

Chemical Technology

Division

Chemical Technology Division

Chemical Technology Division

Chemical Technology Division

Chemical Technology

Division by H. A. Arafat and R. A. Leonard

Chemical Technology

Division

Chemical Technology

Division

Chemical Technology

Division

Chemical Technology

Division

Chemical Technology

Division

Chemical Technology

Division

Chemical Technology

Division

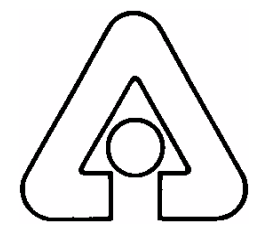

Argonne National Laboratory, Argonne, Illinois 60439

operated by The University of Chicago

for the United States Department of Energy under Contract W-31-109-Eng-38

Chemical Technology

Division

Chemical Technology

Division

Chemical Technology

Division

Chemical Technology

Division 


\begin{abstract}
Argonne National Laboratory, with facilities in the states of Illinois and Idaho, is owned by the United States Government and operated by The University of Chicago under the provisions of a contract with the Department of Energy.
\end{abstract}

\footnotetext{
DISCLAIMER

This report was prepared as an account of work sponsored by an agency of $t$ Government. Neither the United States Government nor any agency th University of Chicago, nor any of their employees or officers, makes any war implied, or assumes any legal liability or responsibility for the accuracy, usefulness of any information, apparatus, product, or process disclosed, or ro use would not infringe privately owned rights. Reference herein to any spe product, process, or service by trade name, trademark, manufacturer, or oth necessarily constitute or imply its endorsement, recommendation, or favorin States Government or any agency thereof. The views and opinions of $\mathrm{d}$ expressed herein do not necessarily state or reflect those of the United States any agency thereof, Argonne National Laboratory, or The University of Chicag
}

Available electronically at http://www.doe.gov/bridge

Available for a processing fee to U.S. Department of Energy and its contractors, in paper, from:

U.S. Department of Energy

Office of Scientific and Technical Information

P.O. Box 62

Oak Ridge, TN 37831-0062

phone: (865) 576-8401

fax: (865) 576-5728

email: reports@adonis.osti.gov 


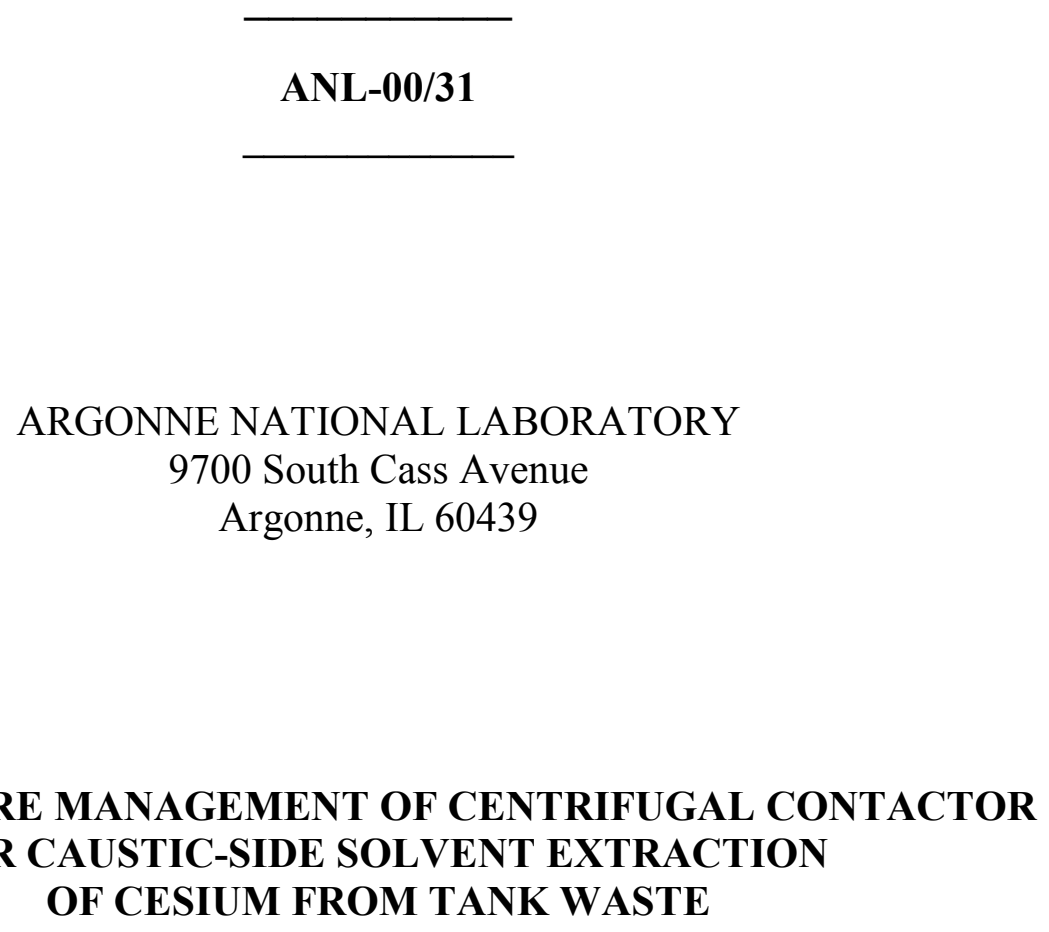

\section{TEMPERATURE MANAGEMENT OF CENTRIFUGAL CONTACTOR FOR CAUSTIC-SIDE SOLVENT EXTRACTION OF CESIUM FROM TANK WASTE}

by

H. A. Arafat and R. A. Leonard

Chemical Technology Division

May 2001 



\section{TABLE OF CONTENTS}

\section{$\underline{\text { Page }}$}

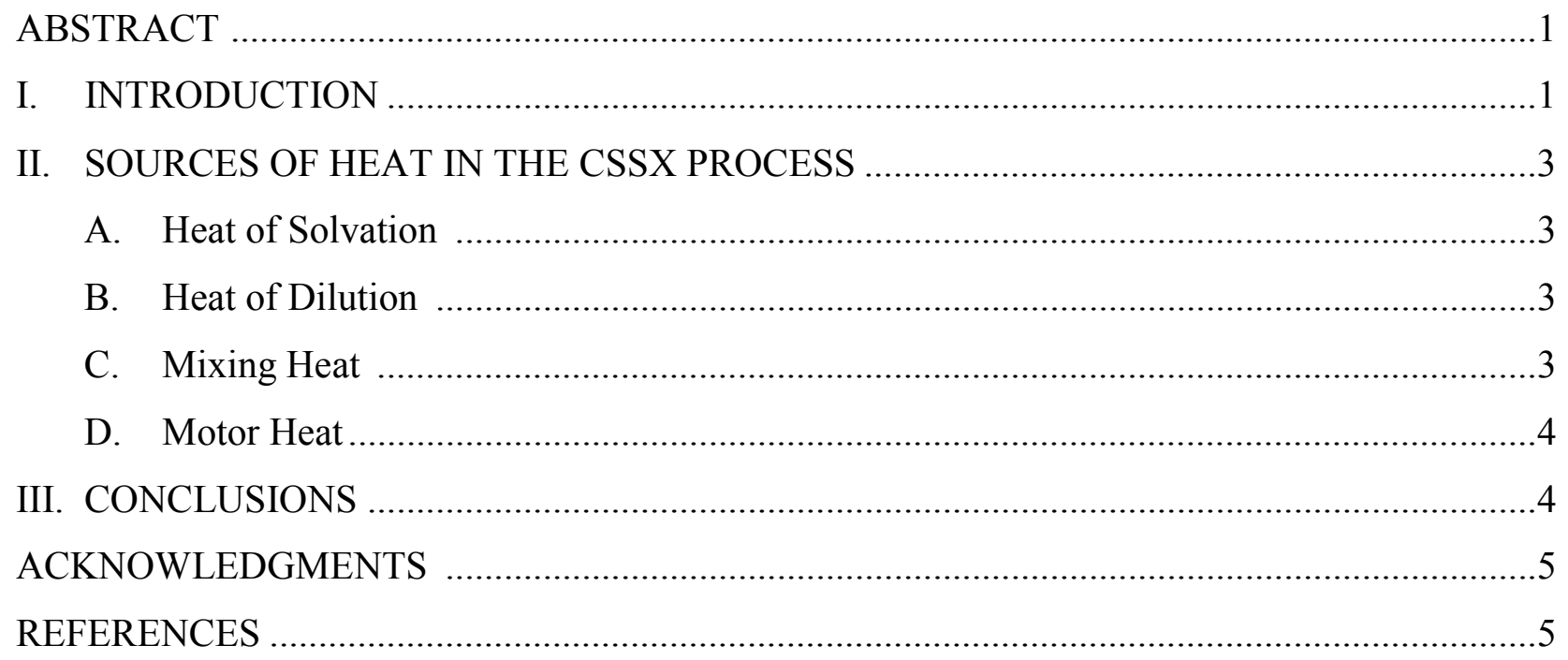




\section{LIST OF FIGURES}

$\underline{\text { No }}$

$\underline{\text { Title }}$

$\underline{\text { Page }}$

1. Flowsheet for CSSX Process Proof-of-Concept Test with Solvent Recycle.....................2

2. Annular Region of 2-cm Contactor during Testing ...............................................4 


\title{
TEMPERATURE MANAGEMENT OF CENTRIFUGAL CONTACTOR FOR CAUSTIC-SIDE SOLVENT EXTRACTION OF CESIUM FROM TANK WASTE
}

\author{
by
}

\author{
H. A. Arafat and R. A. Leonard
}

\begin{abstract}
A 32-stage centrifugal contactor underwent proof-of-concept testing for its potential use in caustic-side solvent extraction for removal of cesium from radioactive waste now stored in underground tanks at the Savannah River Site. This contactor met the performance goals. Maintaining this performance, however, depends on adequate temperature management. Subsequent calculations and measurements determined the effect of several sources of heat on the temperature of the liquid inside the contactor stages: heats of solvation and dilution, heat generated by the rotor in the mixing zone, and heat from the motor used to spin the rotor. The results indicated that over $90 \%$ of the heat comes from the motors, generating $12 \mathrm{~W}$ of thermal energy per stage. It was concluded that satisfactory temperature management of the contactor should be achievable by cooling the extraction section to remove $12 \mathrm{~W}$ of heat per stage.
\end{abstract}

\section{INTRODUCTION}

Savannah River Site (SRS) has 34 million gallons of high-level waste in 48 tanks that needs to be cleaned up. As part of the cleanup process, the cesium in this waste will be removed from a solution containing both supernate liquid and dissolved salt cake, then it will be vitrified for disposal. After the cesium is removed, the solution will be immobilized in low-level grout.

Centrifugal contactors are being evaluated for their use in caustic-side solvent extraction (CSSX) to remove the cesium from SRS tank waste. A 32-stage 2-cm centrifugal contactor was used in a proof-of-concept test of the CSSX process at Argonne National Laboratory [LEONARD-2000]. Figure 1 is the flowsheet designed for the 32-stage unit.

The organic solvent used in the CSSX process, which was prepared at Oak Ridge National Laboratory (ORNL), consisted of an extractant (0.01 $\underline{\mathrm{M}}$ BOBCalixC6), a modifier (0.50 $\underline{\mathrm{M}} \mathrm{Cs}-7 \mathrm{SB})$, and a suppressant $(0.001 \underline{\mathrm{M}}$ trioctyl amine) in a branched paraffinic hydrocarbon diluent (Isopar ${ }^{\circledR} \mathrm{L}$ ). To test the flowsheet, a simulant was used in place of the real SRS waste. The simulant was prepared using a recipe provided by SRS [PETERSON-2000]. The simulant contained soluble metal salts and trace organic components. Its major compounds were $2.06 \underline{\mathrm{M}} \mathrm{NaOH}, 2.03 \underline{\mathrm{M} N a N O}{ }_{3}, 0.5 \underline{\mathrm{M} N a N O}, 0.28 \underline{\mathrm{M}} \mathrm{Al}\left(\mathrm{NO}_{3}\right)_{3}, 0.15 \underline{\mathrm{M}} \mathrm{Na}_{2} \mathrm{CO}_{3}$, and $0.14 \underline{\mathrm{M}}$ $\mathrm{Na}_{2} \mathrm{SO}_{4}$. Cesium was added to the simulant as $\mathrm{CsCl}$ at a concentration of $1.4 \times 10^{-4} \underline{\mathrm{M}}$. 


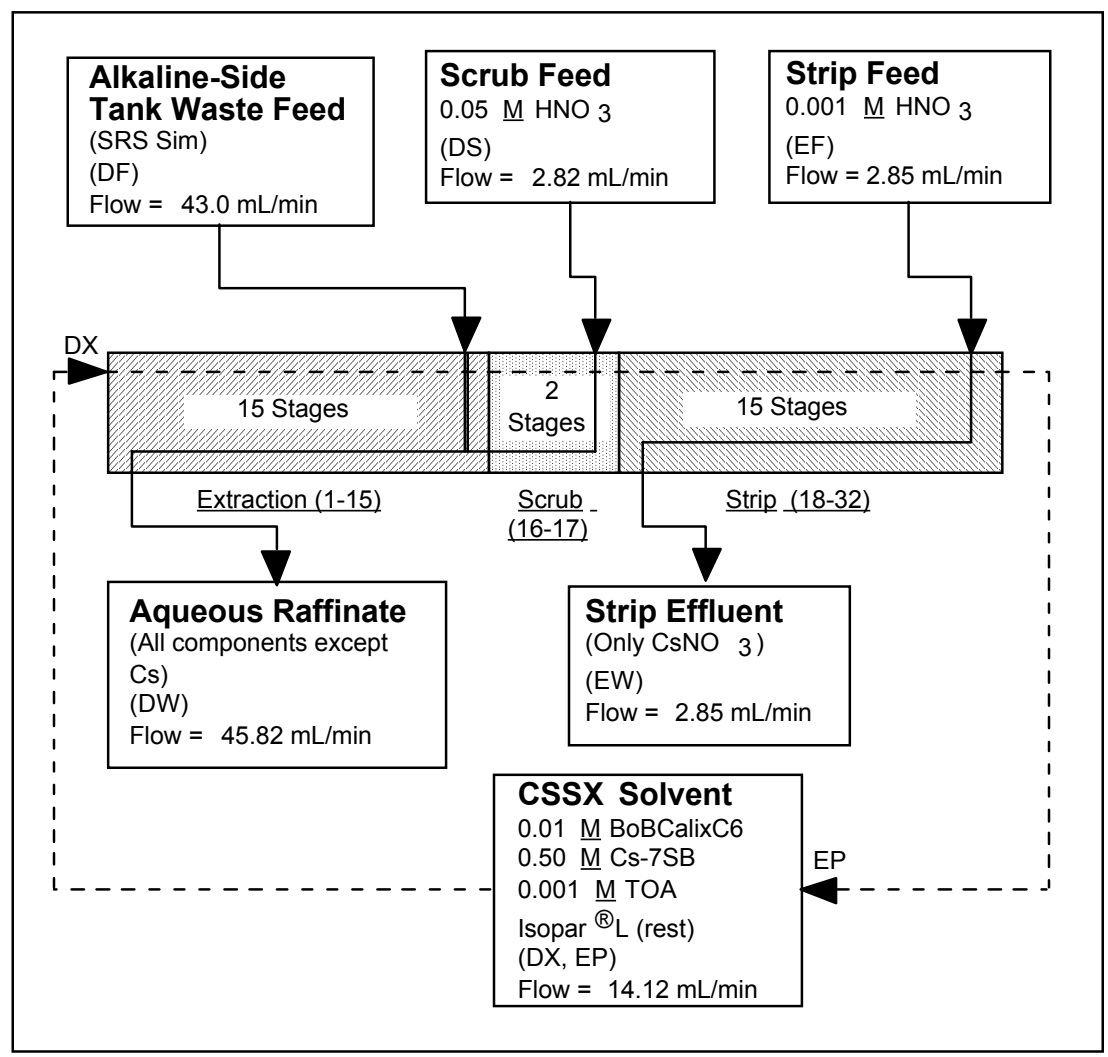

Fig. 1. Flowsheet for CSSX Process Proof-of-Concept Test with Solvent Recycle

In the extraction section (stages 1 through 15 in Fig. 1), cesium is extracted from the alkaline waste feed by the CSSX solvent. Then, as the organic solvent flows through the scrub section (stages 16 and 17), entrained alkaline residues and weakly extracted potassium are removed from the solvent. In the strip section (stages 18 through 32), cesium is stripped from the CSSX solvent into dilute nitric acid.

To characterize the performance of the CSSX process with respect to cesium removal and concentration, two values are used: decontamination factor and concentration factor. The decontamination factor, which indicates the effectiveness of cesium removal from the waste feed, is defined as the cesium concentration in the waste feed divided by the cesium concentration in the aqueous raffinate $([\mathrm{DF}] /[\mathrm{DW}])$. The concentration factor is an indication of the cesium concentration in the strip effluent. It is defined as the cesium concentration in the aqueous strip effluent divided by the cesium concentration in the waste feed ([EW]/[DF]). The goals set for the proof-of-concept tests were a decontamination factor of 40,000 and a concentration factor of 15. Both these goals were met [LEONARD-2000].

The amount of cesium transferred between the aqueous and organic phases in the contactor depends on the distribution ratio (or the $\mathrm{D}$ value) of cesium between the two phases. The D value for cesium in the CSSX process is a strong function of temperature, decreasing as temperature increases [BONNESEN-2000]. Thus, a lower temperature favors the required transfer of cesium to the organic phase in the extraction section. A higher temperature favors the required transfer of cesium to the aqueous phase in the strip section. 
Previous results [LEONARD-2000] indicated that the temperature of the extraction section must be kept below $32^{\circ} \mathrm{C}$ to maintain the high $\mathrm{D}$ value needed in this section. Also, the $\mathrm{D}$ values given in [BONNESEN-2000] indicate that the temperature of the strip section must be kept at $25^{\circ} \mathrm{C}$ or higher to maintain a low $\mathrm{D}$ value in this section. Without external control of the solution temperatures, we found that the temperatures exceed the $32^{\circ} \mathrm{C}$ limit in the extraction section.

\section{SOURCES OF HEAT IN THE CSSX PROCESS}

Four sources of heat contribute to the rise of liquid temperature inside the contactor: (1) heat of solvation, (2) heat of dilution, (3) heat generated by the turbulent mixing in the mixing zone, and (4) heat dissipated by each motor. Figure 2 shows the liquid flow in the annular region of a single stage of the 2 -cm contactor during testing.

\section{A. Heat of Solvation}

The heat of solvation is the amount of heat evolved or absorbed as compounds are transferred from the aqueous simulant to the organic solvent. To estimate the heat of solvation, we began by adding $20 \mathrm{~mL}$ of fresh solvent to $100 \mathrm{~mL}$ of fresh SRS simulant in a $250 \mathrm{~mL}$ bottle. The mixture was then shaken vigorously by hand for a few minutes. The temperature was measured before and after shaking and determined to have increased by $1.2^{\circ} \mathrm{C}$. Based on the flow rates shown in Fig. 1, this temperature increase corresponds to an average of $0.3 \mathrm{~W}$ per stage for each of the 15 stages in the extraction section. This represents an upper bound for the heat of solvation, as some of this temperature rise is likely to be due to the bottle having been shaken.

\section{B. Heat of Dilution}

The heat of dilution is the amount of heat evolved or absorbed upon the dilution of feed solution entering stage 15 , with the scrub solution flowing from stage 16 into stage 15 . In this step, the waste simulant $(43 \mathrm{~mL} / \mathrm{min})$ is diluted by a factor of $6.6 \%$ upon contacting the scrub flow $(2.82 \mathrm{~mL} / \mathrm{min})$. Heats of dilution for $\mathrm{NaOH}$ and $\mathrm{NaNO}_{3}$ will contribute most to the overall heat of dilution because these two compounds have the highest concentration in the feed simulant. The enthalpy-concentration diagram for $\mathrm{NaOH}$ in water [PERRY-1984] shows that the temperature increase when adding $6 \%$ water to $2 \mathrm{M} \mathrm{NaOH}$ solution is less than $1^{\circ} \mathrm{C}$. This exothermic heat of dilution will be partially offset by the endothermic heat of dilution of $\mathrm{NaNO}_{3}$ (-5.03 kg-cal [LANGE-1961]). Thus, the heat of dilution is less than $0.2 \mathrm{~W}$ per stage when averaged over the 15 stages of the extraction section. This represents an upper bound for the heat of dilution.

\section{Mixing Heat}

The amount of heat generated in the contactor mixing zone by the spinning rotor was calculated to be $0.37 \mathrm{~W}$ and $0.29 \mathrm{~W}$ per stage for the extraction and strip sections, respectively. These values were calculated by using a correlation for turbulent flow of liquid between two flat parallel plates as an approximation [KNUDSEN-1958]. 


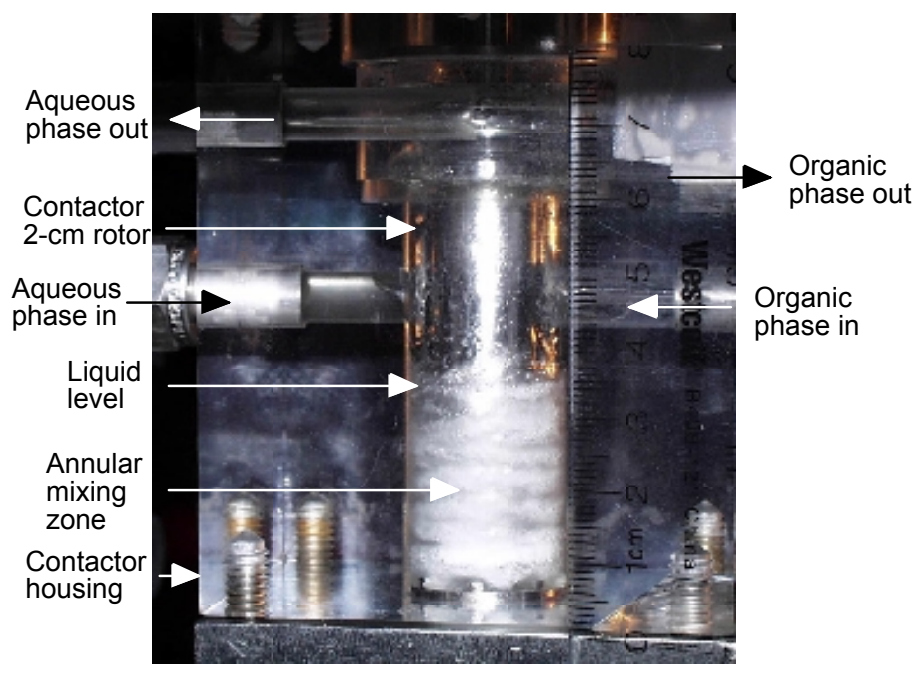

Fig. 2. Annular Region of 2-cm Contactor during Testing

\section{Motor Heat}

Inside the 2-cm contactors, heat is generated by the $12-\mathrm{W}$ motor that is used to spin the rotor. The motor is mounted on a stainless steel plate which directly contacts the stage housing. Most of the motor power is transformed into thermal energy, which is dissipated to the surrounding air via natural convection or to the stainless steel stage housing via thermal conduction. Experiments were performed to evaluate the effect of motor heat on stage temperature. In these experiments, the motor was run without flowing liquid into the stage, and the external stage body temperature was measured. These experiments showed that a running motor increased the stage housing temperature from $25^{\circ} \mathrm{C}$ to $34.4^{\circ} \mathrm{C}$ in $2 \mathrm{~h}$ and up to $39.5^{\circ} \mathrm{C}$ in 16 $\mathrm{h}$. The finding indicates that motor heat is, by far, the most significant portion of the total heat load at each contactor stage. Thus, $12 \mathrm{~W}$ per stage represents an upper bound for the heat generated by the motor.

\section{CONCLUSIONS}

These results show that the stage temperature will rise above room temperature (to as high as $\left.39.5^{\circ} \mathrm{C}\right)$ due to the motor heat. Much smaller amounts of heat $(<10 \%)$ are added from other sources. To counteract this effect, a number of option were considered including design modifications (e.g. changing the type of motor used or the proximity of the motor to the rotor), and operational modifications such as using a chiller to cool the extraction stages. It was decided that using a chiller is the simplest and most feasible solution to remove a total heat load of $180 \mathrm{~W}$ from the extraction section, that is, $12 \mathrm{~W} /$ stage. Such a design would keep the extraction stages between 20 and $32^{\circ} \mathrm{C}$, where operation is acceptable. The strip section need not be chilled because its operating temperature range is higher than $25^{\circ} \mathrm{C}$. 


\section{ACKNOWLEDGMENTS}

This work was supported by the Office of Environment Management of the U.S. Department of Energy through (1) the Office of Project Completion and (2) the Tank Focus Area of the Office of Science and Technology under Contract W-31-109-Eng-38 with Argonne National Laboratory, managed by the University of Chicago.

\section{REFERENCES}

BONNESEN-2000

P. V. Bonnesen, L. H. Delmau, B. A. Moyer, and R. A. Leonard, "A Robust AlkalineSide CSEX Solvent Suitable for Removing Cesium from Savannah River High Level Waste," Sol. Extr. Ion Exch. 18 (6), 1079-1107 (2000).

KNUDSEN-1958

J. G. Knudsen and D. L. Katz, Fluid Dynamics and Heat Transfer, McGraw-Hill, New York (1958).

LANGE-1961

N. A. Lange, Handbook of Chemistry, $10^{\text {th }}$ Edition, McGraw-Hill, New York (1961).

LEONARD-2000

R. A. Leonard, S. B. Aase, H. A. Arafat, C. Conner, J. R. Falkenberg, and G. F. Vandegrift, Proof-of-Concept Flowsheet Tests for Caustic-Side Solvent Extraction of Cesium from Tank Waste, Argonne National Laboratory Report ANL-00/30 (2000).

PETERSON-2000

R. A. Peterson, Preparation of Simulated Waste Solutions for Solvent Extraction Testing, Westinghouse Savannah River Company Report WSRC-RP-2000-00361, Rev. 0 (2000).

PERRY-1984

R. H. Perry, D. W. Green, and J. O. Maloney, Perry's Chemical Engineers' Handbook, $6^{\text {th }}$ Edition, McGraw-Hill, New York (1984). 


\section{Distribution for ANL-00/31}

Internal:
S. B. Aase
R. E. Einziger
J. Sedlet
H. Arafat (10)
J. E. Harmon
M. J. Steindler
D. B. Chamberlain
R. A. Leonard (5)
Y. I. Chang
D. Lewis (2)
G. F. Vandegrift
C. Conner
M. C. Regalbuto
TIS Files

External:

DOE-OSTI

ANL-E-Library

ANL-W-Library

Chemical Technology Division Review Committee Members:

H. U. Anderson, Emeritus, University of Missouri-Rolla, Rolla, MO

A. L. Bement, Jr., Purdue University, West Lafayette, IN

C. L. Hussey, University of Mississippi, University, MS

M. V. Koch, University of Washington, Seattle, WA

V. P. Roan, Jr., University of Florida, Palm Beach Gardens, FL

J. R. Selman, Illinois Institute of Technology, Chicago, IL

J. S. Tulenko, University of Florida, Gainsville, FL

J. F. Birdwell, Oak Ridge National Laboratory, Oak Ridge, TN

P. V. Bonnesen, Oak Ridge National Laboratory, Oak Ridge, TN

S. Campbell, Westinghouse Savannah River Company, Aiken, SC

J. T. Carter, Westinghouse Savannah River Company, Aiken, SC

S. D. Fink, Westinghouse Savannah River Company, Aiken, SC

M. Geeting, Westinghouse Savannah River Company, Aiken, SC

R. T. Jubin, Oak Ridge National Laboratory, Oak Ridge, TN

L. N. Klatt, Oak Ridge National Laboratory, Oak Ridge, TN

J. D. Law, Idaho National Engineering and Environmental Laboratory, Idaho Falls, ID

J. McCullough, USDOE, Aiken, SC

B. A. Moyer, Oak Ridge National Laboratory, Oak Ridge, TN

M. Norato, Westinghouse Savannah River Company, Aiken, SC

L. M. Papouchado, Westinghouse Savannah River Company, Aiken, SC

R. A. Peterson, Bechtel-Washington Process Technology, Richland, WA

R. A. Pierce, Westinghouse Savannah River Company, Aiken, SC

K. J. Rueter, Bechtel-Washington Process Technology Richland, WA

P. Rutland, Bechtel-Washington Process Technology Richland, WA

S. Schlahta, BNFL, Aiken, SC

W. L. Tamosaitis, Westinghouse Savannah River Company, Aiken, SC

M. C. Thompson, Westinghouse Savannah River Company, Aiken, SC

T. A. Todd, INEEL, Idaho Falls, ID

V. Van Brunt, University of South Carolina, Columbia, SC

D. D. Walker, Westinghouse Savannah River Company, Aiken, SC 